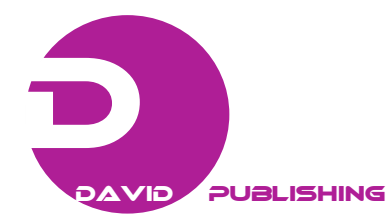

\title{
Chemical Vertical Zonality in Silicate Nickel Deposit in Gllavica, Republic of Kosovo
}

\author{
Bedri Durmishaj ${ }^{1}$, Sylejman Hyseni ${ }^{1}$ and Ilir Alliu ${ }^{2}$ \\ 1. Department of Geology, Faculty of Geosciences, Public University of Mitrovice (FGT-Mitrovice), Mitrovice 40000, Republic of \\ Kosovo \\ 2. Department of Earth Sciences, Faculty of Geology and Mining, Polytechnic University of Tirana, Tirana 1001, Albania
}

\begin{abstract}
In this paper is presented chemical vertical zonality in mineral deposit nickel silicate Gllavica that is located near to the airport of Pristina. In this study were included detailed geological research of the first phase and the second pahse in deposit. According to geological exploration is presented zonality in direction of the depth of the nickel silicate deposit. Geological exploration have appeared vertical profile by zones from the surface to the depth of the deposit. The content of nickel increases nontronite zone, according to the results shown in this prospecting zone the nickel mineralization reaches higher values in the zone nontronite serpentinite.
\end{abstract}

Key words: Vertical zonality, exploration, Gllavica deposit, Ni-silicate, Kosovo.

\section{Introduction}

Kosovo is situated in the central part of the Balkan Peninsula. In the southwest, it is bordered by Albania, in the west by Montenegro, in the north and east by Serbia and in the southeast by Macedonia. The territory extends within longitudes $41^{\circ} 50^{\prime} 58^{\prime \prime} \mathrm{N}$ and $43^{\circ} 15^{\prime} 42^{\prime \prime}$ $\mathrm{N}$ and within latitudes $20^{\circ} 01^{\prime} 30^{\prime \prime} \mathrm{E}$ and $21^{\circ} 48^{\prime} 02^{\prime \prime} \mathrm{E}$ [1].

Kosovo covers a surface area of $10,887 \mathrm{~km}^{2}$. It is characterized by an average altitude of $800 \mathrm{~m}$ above, but shows considerable changes in relief and morphology of terrain (Fig. 1).

\section{Nickel Exploration in Mineral Deposit in Gllavica}

Exploration of silicate nickel ores in the territory of Kosovo date from 1958 which define the first occurrence of nickel minealization on Gllavica territory near the magnesite mine in Magura. In 1961 begin detailed research in the broad area of nickel silicate deposit. These detailed geological exploration

Corresponding author: Bedri Durmishaj, associate professor. research fields: mineralogy and geochemistry. E-mail: bdurmishaj@hotmail.com. enabled Glavica deposit outline. [2, 3]. Exploration works in nickel deposit "Gllavica" were conducted in two phases. First phase of the research work was carried out from 1961 to 1997 . The second phase of research was conducted during 2006 and 2007 [4]. Deposits ore body thickness varies from 2-32 m, the average thickness is about $11 \mathrm{~m}$ [3]. In the first phase of exploration, there were a total of 459 drillings and in the second phase were realized 192 exploration drillings with network $50 \times 50 \mathrm{~m}$ (Fig. 2).

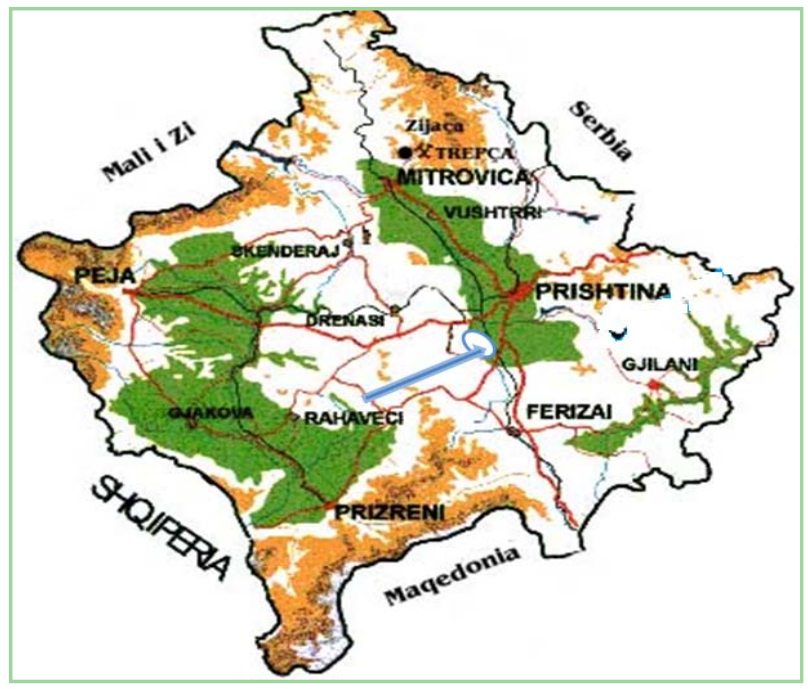

Fig. 1 Geographic map of Kosovo 1: 1,000,000. 


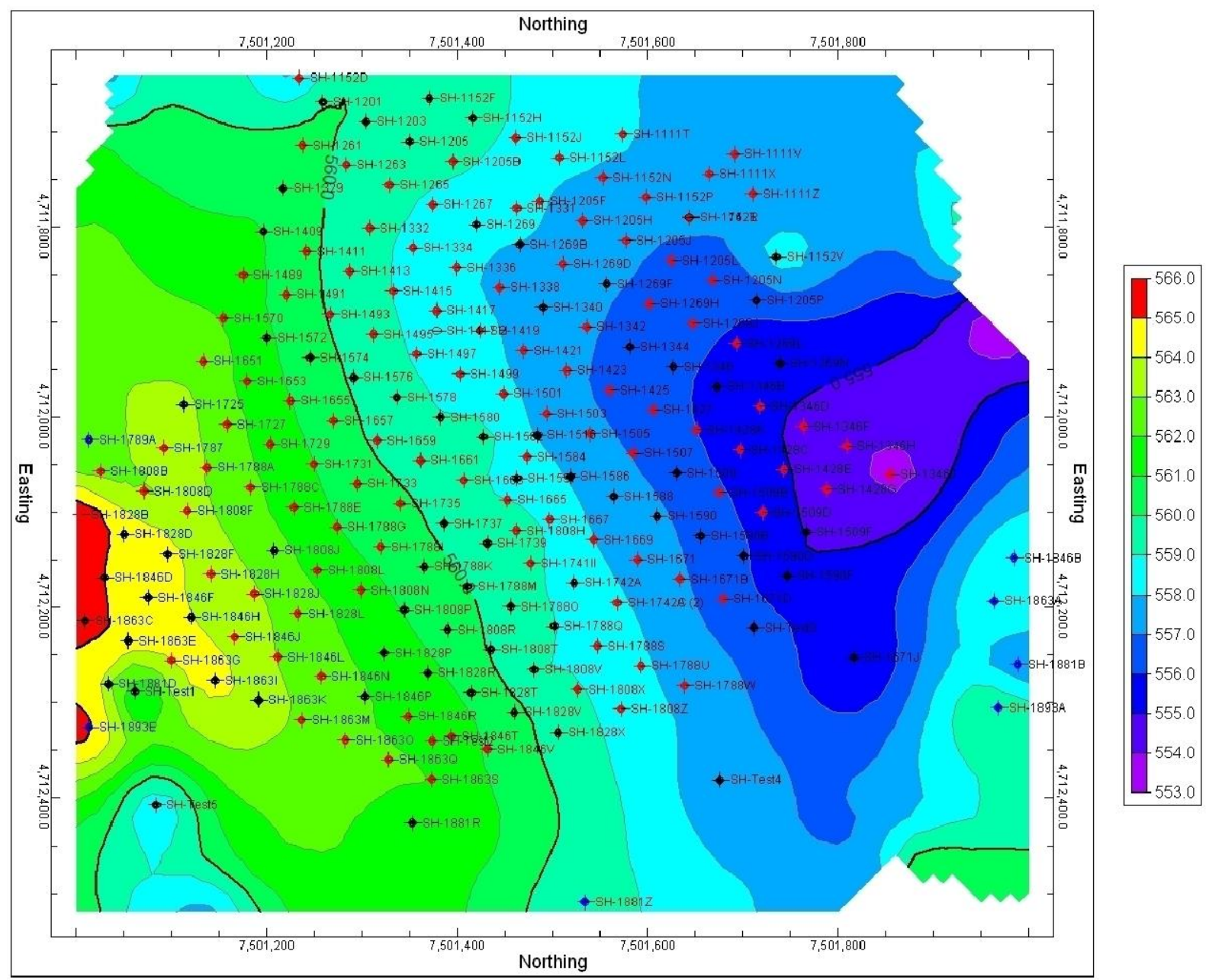

Fig. 2 Modelling of 2D drilling, source [4].

\section{Geology of Mineral Deposit}

Formations that make up this field are green shale Paleozoic, peridotites-serpentinite, deposits of Pliocene and Quaternary. Deposit of Ni-silicate "Gllavica" is part massif of Golesh and lies in the south-eastern part of the massif [5]. Overall depth of the crust breaking rich in Ni reaches $60-80 \mathrm{~m}$.

Deposit was formed in specific conditions during the formation of laterite crust disposition of ultramafic rocks. In mineral deposit "Gllavica" top to down direction is separated in these zones (Fig. 3):

A-red clay zone;

B-opal zone;

C-nontronite clay zone;

D-serpentinite zone;
E-peridotites fresh zone.

Red clay zone (A). This zone is composed form clay yellowish to red colour containing fragments of opal.

Mineral represented in this area is goethite, and much less appear opal, quartz and halloysite. In the upper part of this zone is determined the presence of these elements (Fig. 4).

Characteristic of this part is to establish the composition of the local Co due to the appearance most of $\mathrm{MnO}$, and $\mathrm{Fe}$, and $\mathrm{Ni}$ composition is quite low. Characteristic of this profile is the beginning of increasing Ni composition of Mg. This part of the area made the transition to the higher parts of the area mineralized. The thickness of this zone varies from 5.1 $\mathrm{m}$ to $7.2 \mathrm{~m}$; part of the area is altered. 


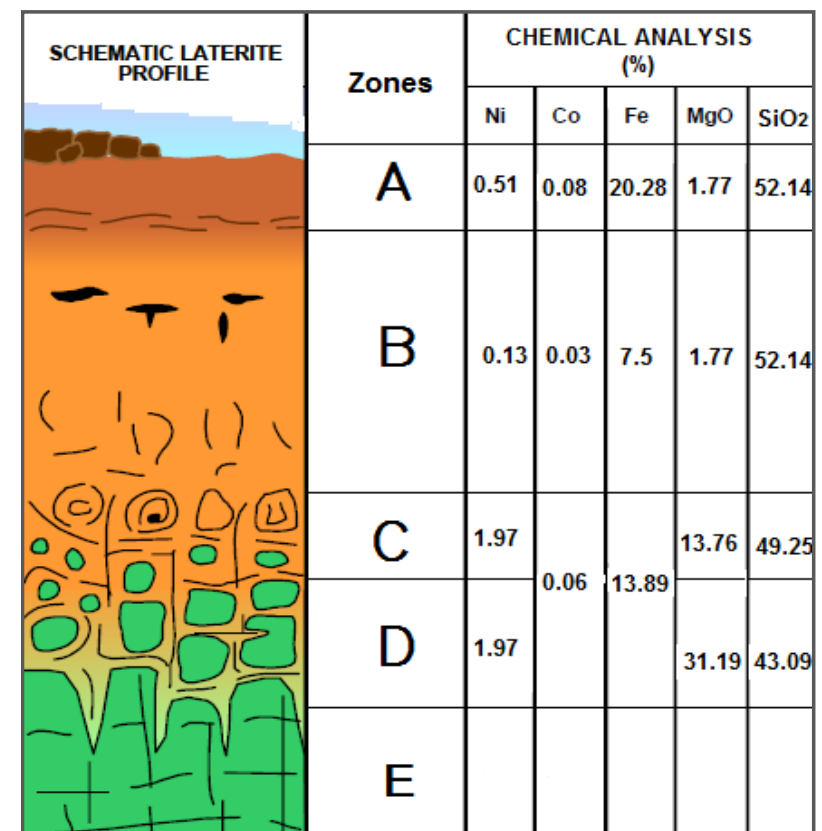

Fig. 3 Schematic laterite profiles in the nickel silicate deposit of Gllavica.

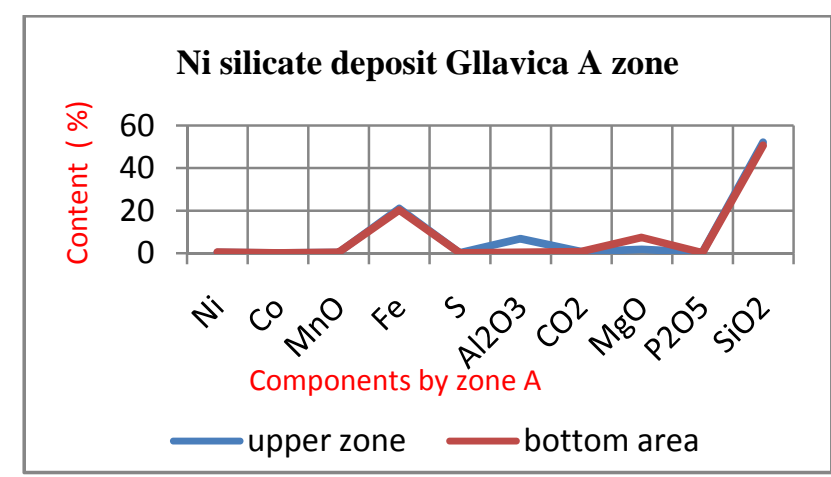

Fig. 4 Distributions of elements in the clay zone.

Opal zone (B) is not a clear profile, it is developed in the upper parts of the deposit, but appears also in the lowest levels in the clay zone of nontronites, in-depth of deposit this zone closes [6]. This zone appears compact with fragments in composition of clay mineralized iron, iron hydroxide and manganese oxides. Chemical analysis of this zone are shown in Fig. 5.

This area is characterized by relatively high $\mathrm{SiO}_{2}$, low composition Fe and very low $\mathrm{MgO}, \mathrm{Ni}$ and $\mathrm{Co}$. The thickness of this zone ranges from $1.0 \mathrm{~m}$ to $4.0 \mathrm{~m}$. In crust of alteration hartzburgite are presented in the form of net or vein as opal and compact mass. Main component is opal; build about $80 \%$ of this area.

Nontronite zone (C) represents the largest concentration area Ni (Fig. 6). Ni minerals are pimelite and nontronite. This area includes the central part of the deposit and represents the lower level to which has reached up to change hartzburgite and fresh peridotite in its entirety and have moved to altered crust products [7]. The area is built out of clay material nontronite with yellow colours close to that of the yellow-green in the lower parts containing impregnation and seam hydrosilicate Ni-pimelite. Percentage of goethite rises toward the surface and in the upper parts of this zone, nontronite fully assignable goethite and free silicon. In the lower secondary separated clinohryzotile along with pimelite, which affect the growth of $\mathrm{MgO}$ in low profile nontronite zone [8].

Serpentinite zone (D) lies under the area of nontronite clay. These rocks are coloured in green, green to yellow to dark yellow. Alteration is made of the primary ingredients laundering processes surface initial stage where olivine and enstatite have become nontronite or serpentinite [5]. Secondary products in this segregated area of quartz reef and opal amounts of magnesium secondary and hydration silicates of magnesium. Main minerals of this area are nontronite and serpentine. In smaller amounts are found minerals of goethite and hematite.

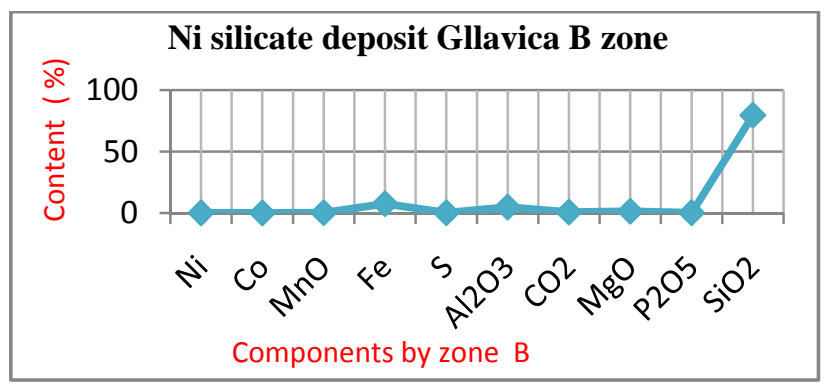

Fig. 5 Distributions of elements in the opal zone.

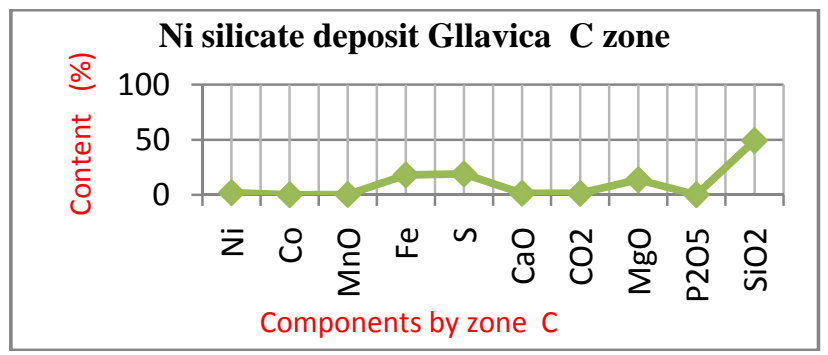

Fig. 6 Distributions of elements in the nontronite zone. 
Microcrystalline quartz, partly opal and cristobalite are presented in the form of vertical veins that fill empty space of alerted hartzburgite [8]. The main components of this area are magnesium legislation, sepiolite and $\beta$ kerolite. Pimelite appear in the upper parts of this area and this greatly ore nickel mineralization.

This area is characterized by high values of $\mathrm{MgO}$ component (Fig. 7) which is associated with the appearance of magnesium transferred from the water during filtration in depth. Cobalt (Co) has decreased significantly and $\mathrm{Ni}$ is above the percentage of the metal taken for calculation of economic reserves $(\mathrm{Ni}=$ $0.5 \%$ ). The thickness of this zone is quite variable and ranges from 4.0 to $23.0 \mathrm{~m}$.

This zone represents the footwall of the deposit where dominate dunite. In the upper part of this zone passes in the serpentinization peridotite where the process of alteration of primary components has a very low intensity and have been almost completely preserved in structure and composition [5].

In this area falls a content of $\mathrm{SiO}_{2}$ and increasing the content of $\mathrm{MgO}$ components (Fig. 8), as a result of that

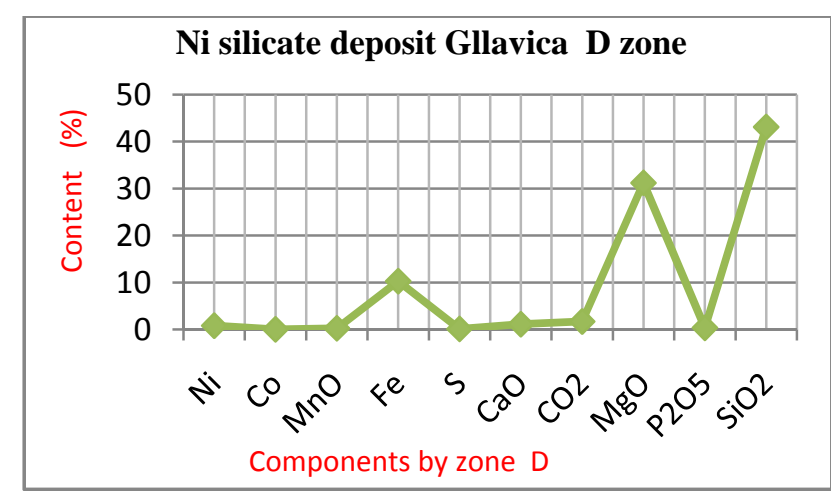

Fig. 7 Distributions of elements in the serpentinite zone.

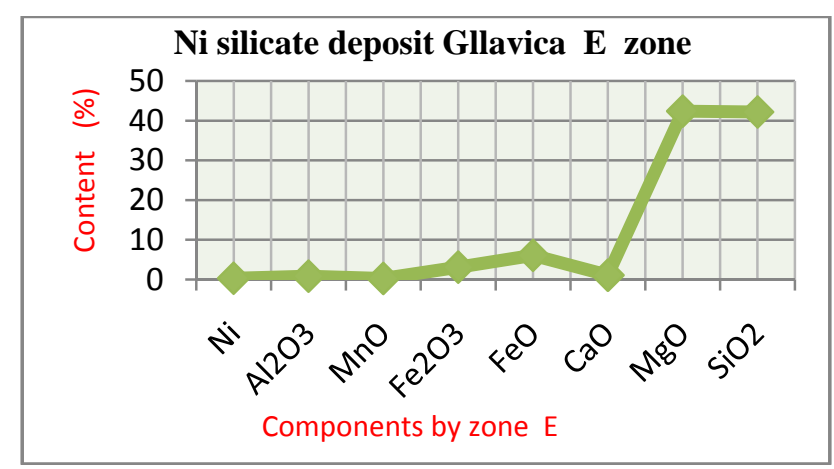

Fig. 8 Distributions of elements in the peridotite zone. presentation, fresh peridotites. Contents of $\mathrm{Ni}$ and $\mathrm{Co}$ in the area falls and appears only trace.

\section{Geological Reserves in Mineral Deposit in Gllavica}

The Republic of Kosovo is one of the influential states in the region in terms of Ni ore. In our country meet $\mathrm{Ni}$ mineral deposits but also exploitation and melting of $\mathrm{Fe}-\mathrm{Ni}$, which makes it quite easy and convenient as well as research exploitation [7, 8]. For this reason, our country would be reasonable to find reserves where cut of grade is less than $1 \% \mathrm{Ni}$ and $\mathrm{Fe}$ $-20 \%$. Statistical data for $\mathrm{Ni}$ and other components for mineral deposit Gllavica according to data (Table 1) average distribution of $\mathrm{Ni}$ is very high $1.16 \%$ (Table 2).

\section{Materials and Methods}

To study in our paper we have used a large number of geological data of the first phase and second in exploration mineral deposit $\mathrm{Ni}$ silicate Gllavica. Sampling is taken by us settlement and drilling exploration of profiles. Chemical analysis and spectral-chemical are realized in experimental laboratory self mine and laboratory mines Trepça. Analyses were made in macro and micro elements. For the study of laterite areas, we have exploited elements that are typical laterite deposit (Tables 1 and 2).

\section{Results and Discussion}

The results presented in Table 1 and Table 2 is from the second phase deposit Gllavica show that have quantity and better quality than the first phase. This discussion is qualitatively different than the result of the second stage has a number of great and detailed geological researches in the fields. The study of this deposit according to the results (Table 2), presented shows that the average content of $\mathrm{Ni}$ for the entire deposit is $1.16 \%$, for the production of today's Industries are high economic value. 
Table 1 Geological reserves in Gllavica mineral deposit.

\begin{tabular}{llllllll}
\hline \multirow{2}{*}{ Geological reserves } & \multicolumn{5}{c}{ Percentage (\%) } & & \multicolumn{2}{c}{ Quantity } \\
\cline { 2 - 5 } & $\mathrm{Ni}$ & $\mathrm{SiO}_{2}$ & $\mathrm{Fe}_{2} \mathrm{O}_{3}$ & $\mathrm{Co}$ & & Ton \\
\hline Total & 1.02 & 51.70 & 22.63 & 0.04 & $7,227.15200$ & $13,156.061$ \\
\hline
\end{tabular}

Table 2. Statistical parameters of the distribution of Ni metal and other components in Gllavica mineral deposit.

\begin{tabular}{lllllll}
\hline & Thickness $(\mathrm{m})$ & $\mathrm{Ni}$ & $\mathrm{SiO}_{2}$ & $\mathrm{Fe}_{2} \mathrm{O}_{3}$ & $\mathrm{MgO}$ & $\mathrm{Co}$ \\
\hline Arithmetic average & 16.54 & 1.16 & 52.07 & 21.52 & 10.66 & 0.04 \\
Standard error & 0.49 & 0.02 & 0.50 & 0.40 & 0.25 & 0.00 \\
Median & 14.80 & 1.12 & 52.01 & 20.21 & 10.07 & 0.03 \\
Mode & 12.50 & 0.95 & 48.56 & 14.25 & 8.00 & 0.02 \\
Standard deviation & 9.85 & 0.37 & 9.78 & 7.73 & 4.40 & 0.03 \\
Variation coefficient & 59 & 32 & 19 & 36 & 41 & 82 \\
Kurtosija & -0.05 & 1.34 & 0.48 & 1.85 & 2.23 & 23.73 \\
Asymmetry & 0.57 & 0.73 & -0.18 & 1.09 & 0.99 & 3.78 \\
Rank & 52.50 & 2.69 & 70.11 & 51.27 & 31.31 & 0.33 \\
Minimum & 0.50 & 0.02 & 5.69 & 9.48 & 0.00 & 0.00 \\
Maximum & 53.00 & 2.71 & 75.80 & 60.75 & 31.31 & 0.33 \\
Amount & $6,600.10$ & 465.37 & $19,682.09$ & $8,155.77$ & $3,292.75$ & 15.81 \\
Number of drilling & 399 & 400 & 378 & 379 & 309 & 380 \\
\hline
\end{tabular}

\section{Conclusion}

According to the data presented in the paper for laterite profile to deposit $\mathrm{Ni}$ silicate shows legality according formation theoretical model of laterite deposits. In mineral deposit of $\mathrm{Ni}$ silicate Gllavica zonality is noticed quite clearly form lateritic profile. This zonality shows that we have a distribution of $\mathrm{Ni}$, $\mathrm{Co}, \mathrm{Fe}, \mathrm{MgO}$ and $\mathrm{SiO}_{2}$ which varies by area. Distribution of Ni, Co, Fe clay zone in the area opal have decrease and nontronite, serpentinite zone have increased content that $\mathrm{Ni}, \mathrm{Fe}, \mathrm{Co}$ and $\mathrm{MgO}$. Geological profiles nontronite, serpentinite is main areas mineralized $\mathrm{Ni}$ silicate. In the area of fresh peridotite have high content of $\mathrm{MgO}$ and $\mathrm{SiO}_{2}$ which are main components in the formation of rocks ultra basic that once also present foot wall part of the deposit.

\section{References}

[1] Krasniqi, A. 2012. "Nickel Deposits in Kosovo and Their Economic Importance." Master thesis,
FGT-Mitrovice.

[2] Sahiti, F. 2010. "Geological Designed Models in Their Application Nickel Deposit Gllavica." Master thesis, FGT-Mitrovice.

[3] Hyseni, S., Durmishaj, B., Pruthi, V., Frangu, S., Alikaj, P., Hasani, I., Fetahaj, B., Krasniqi, R., and Hasani, A. 2009. "Preparation of Policy and Strategy for Development of Regional Geological Exploration.” Ministry of Energy and Mining (Draft I, II and III), Prishtine.

[4] Hajra, F., Konjuhi, A., Miftari, S., Fazliu, S., Krasniqi, A., Hasani, R., and Ibishi, G. 2008. Geological Elaborate Calculation Reserves for Nickel in Deposit Gllavica (INKOS), Prishtine.

[5] Martson, R. 1984. Nickel Mineralization in Western Australia. Perth: Geological Survey of Western Australia.

[6] Matijeviç, I. 1980. Report of Regional Research of Silicate Ore in KSA Kosovo. Geological research Institute Belgrade.

[7] Abazi, S., and Hyseni, S. 2012. "Perspective Research Laterite Areas of the Ni Silicates in Kosovo." Presented at the International Conference on 90th Anniversary of the Geology of Albania, Tirana.

[8] Maksimoviç, L. 1962. "Problems of Research of Ni in the Ultra Basic Rocks." Presented at the Scientific Symposium, Belgrade. 